\title{
KONSEP METODE HALAQAH DALAM PEMBELAJARAN PAI DAN BUDI PEKERTI
}

\author{
Oleh: \\ Ilham dan Sukrin HT \\ Institut Agama Islam (IAI) Muhammadiyah Bima \\ ilhamham903@gmail.com
}

\begin{abstract}
Abstrak:
Metode pembelajaran Halaqah termasuk instrumen pembelajaran yang cukup ideal dapat dijadikan sebagai acuan pembelajaran PAI. Secara teknis, metode Halaqah akan menjadi instrumen pengendali interaksi kegiatan pembelajaran seorang peserta didik dengan para guru/Kiyai. Metode pembelajaran Halaqah ini lebih menitiberatkan kepada kemampuan perseorangan dalam menganalisa dan memecahkan suatu masalah dengan argumen logika pada kitab-kitab tertentu. Seorang guru/Kiyai hanya tampil dalam memimpin jalannya kegiatan proses pembelajaran biasanya menggunakan kitab/buku untuk dipahami oleh peserta didik, menguraikan nama judul sekaligus penulis kitabnya, menjelaskan pentingnya isi kitab yang akan dipelajari. Dengan demikian, muatan konsep metode pembelajaran Halaqah umumnya menekanan para peserta didik untuk meningkatan cara berfikir kritis dan menkonstruksi pengetahuan dalam dirinya yang secara terbimbing para guru/kiyai bertindak sebagai fasilitator dalam setiap interaksi pembelajaran dilingkup satuan pendidikan.
\end{abstract}

Kata Kunci: Metode, Halaqah, Pembelajaran PAI

\section{Pendahuluan}

Model pembelajaran merupakan suatu perencanaan atau suatu pola yang digunakan sebagai pedoman dalam merencanakan pembelajaran di kelas. Metode pembelajaran mengacu pada pendekatan pembelajaran yang akan digunakan, termasuk di dalamnya tujuan-tujuan pengajaran, tahaptahap dalam kegiatan pembelajaran, lingkungan pembelajaran, dan pengelolaan kelas. Menurut Syarfuddin Nurdin menyatakan bahwa model pembelajaran dapat diartikan sebagai cara yang digunakan untuk mengimplementasikan rencana yang sudah disusun dalam bentuk kegiatan 
nyata dan praktis untuk mencapai tujuan pembelajaran. ${ }^{1}$ Sedangkan Rusman menyatakan bahwa model pembelajaran adalah kerangka konseptual yang melukiskan prosedur yang sistematis dalam mengorganisasikan pengalaman belajar untuk mencapai tujuan pembelajaran tertentu, dan memiliki fungsi sebagai pedoman bagi para perancang pembelajaran dan para pengajar dalam merencanakan dan melaksanakan aktifitas belajar mengajar. ${ }^{2}$ Berdasarkan pendapat di atas, bahwa model pembelajaran adalah kerangka konseptual yang melukiskan prosedur sistematik dalam mengorganisasikan pengalaman belajar untuk mencapai tujuan pembelajaran tertentu dan berfungsi sebagi pedoman bagi perancang pembelajaran dan para guru dalam merancang dan melaksanakan proses belajar mengajar.

Model merupakan kerangka konseptual. Sedangkan untuk langkah penerapan pembelajaran menggunakan metode sebagai acuan dalam menyampaikan materi pembelajaran. Metode halaqah mejadi salah satu bagian yang digunakan oleh pendidik dalam strategis pembelajaran. Secara historis metode halaqah telah digunakan sejak masa Rasulullah SAW ketika mengajarkan Islam kepada para sahabat, masjid Nabawi di Madinah menjadi tempatnya. ${ }^{3}$ Selanjutnya terus dilakukan oleh para ulama dalam mengajarkan ilmu kepada muridnya. Diantara masjid-masjid terkenal yang penuh dengan halaqah taklim di era Islam adalah Jami' Al-Manshur di Baghdad, Jami' Amru bin Al-Ash di Fustat, Jami' Al-Umawi di Damaskus, Jami' al-Azhar di Kairo, Masjid an-Nabawi di Madinah Al-Munawwarah, Masjidil Haram di Mekkah, Masjid Al-Jami' di Cordoba dan lain sebagainya. $^{4}$

Pada prinsipnya metode halaqah ini dibimbing oleh para kiyai/guru yang masing-masing memiliki ranah konsentrasi ilmunya tersendiri. guru ini duduk di pojok salah satu tiang masjid, kemudian dikerumuni para siswa

\footnotetext{
${ }^{1}$ Syafruddin Nurdin dan Adriantoni, Kurikulum dan Pembelajaran, (Jakarta, Rajawali Pers, 2016), 180

${ }^{2}$ Rusman, Model-Model Pembelajaran: Mengembangkan Profesionalisme Guru, (Jakarta, Rajawali Pres, 2016), 132

${ }^{3}$ Syafiyyurrahman Al-Mubarakhfuri, Ar-Rahiqul Makhtum, Bahtsun fi As-Sirah An-Nabawiyah ala Shahibina Aidhalish Shalati wa sallam, Terjemah Kathur Suhartdi, Sirah Nabawiyah, (Jakarta, Pustaka Al-Kautsar, 2008), 211

${ }^{4}$ Muhammad Husain Mahasnah, adhwa 'ala Tarikh Al-Ulum inda Al-Muslimin, Diterjemahkan oleh Muhammad Misbah, Pengantar Sejarah Peradaban Islam, (Jakarta, Pustaka Al-Kautsar, 2016), 135
} 
secara melingkar (membentuk halaqah), setelah itu, guru ini menyampaikan kajiannya sesuai dengan konsetrasi keilmuanya. ${ }^{5}$ Dahulu, metode pengajaran di dalam halaqah sangat beragam. Terkadang memakai metode imla' (dikte), terkadang dengan penjelasan dan diskusi. ${ }^{6}$ Metode diskusi bermanfaat bagi siswa dalam belajar dan menambah kepercayaan diri. Metode halaqah menjadi populer digunakan oleh para ulama di surau, dan pondok pesantren di Indonesia sebagai metode pengajaran melalui kitabkitab klasik kepada santri. Sebagai cara untuk menyebarkan ilmu pengetahuan dan ajaran Islam. Seiring dengan perkembangan jaman, metode halaqah tidak saja digunakan pada pondok pesantren tapi juga dapat juga digunakan pada sekolah-sekolah moderen.

\section{Pembahasan}

\section{Hakekat Dan Makna Metode Pembelajaran Halaqah}

Menjadi sesuatu yang mutlak adanya, bahwa proses pembelajaran yang dilakukan pada semua pesantren untuk menelaah isi kitab-kitab berbahasa Arab yang dilakukan oleh kiyai kepada santrinya pada kegiatan proses belajar mengajar, seorang kiyai duduk depan santrinya, kemudian santri membentuk lingkaran mereka duduk menghadap kepada kiyai. Cara seperti itu disebut dengan metode pembelajaran halaqah. Kata halaqah berasal dari bahasa arab yaitu halaqah atau halqah yang berarti lingkaran. ${ }^{7}$ Dalam bahasa Indonesia Hasan Alwi mendefinisikan halaqah sebagai cara belajar atau mengajar dengan duduk di atas tikar dan posisi melingkar. ${ }^{8}$ Sedangkan dalam bahasa Jawa, halaqah ini lebih dikenal dengan wetonan atau bandongan. Istilah halaqah yang dikemukakan oleh Hanun Asrohah merupakan proses belajar mengajar yang dilaksanakan peserta didik dengan melingkari guru yang bersangkutan. ${ }^{9}$ Ibnu Bathuthah melaporkan bahwa menjelang akhir $728 \mathrm{H} / 1326 \mathrm{M}$ bahwa dia mengamati pada malam hari

\footnotetext{
${ }^{5}$ Ahmad Syalabi, At-Tarbiyyah wa At-Ta'lim fi Al-Fikr Al-Islami, (Kairo, 1964), 112

${ }^{6}$ Jalaluddin As-Suyuthi, Thabaqat Al-Huffazh, Dar Al-Kutub Al-Ilmiyyah, Dar AlKutub Al-Islamiyyah, Beirut, 1983

${ }^{7}$ Munawwir, A.W. Kamus al-Munawwir. (Surabaya: Pustaka Progressif, 1997), 153

${ }^{8}$ Hasan Alwi, Kamus Besar Bahasa Indonesia, (Jakarta, Balai Pustaka, tt), 383

${ }^{9}$ Hanun Asrohah, Sejarah Pendidikan Islam, (Jakarta, Logos, 1994), 49
} 
kegiatan keilmuan yang diselenggarakan di masjid Nabawi, dimana ulama dan peserta didik membentuk halaqah, lengkap dengan al-Qur'an dan kitabkitab lain sebagai sumber belajar. ${ }^{10}$

Dari beberapa pendapat di atas halaqah adalah suatu kegiatan belajar mengajar yang dilakukan oleh guru atau kiyai dengan duduk dihadapan santrinya sambil membacakan materi kitab. Para santri yang mengikuti pembelajaran ini duduk dalam bentuk setengah lingkaran dan bersaf-saf. Kiyai/Ustadz senantiasa berusaha membacakan isi kitab, kata per kata atau kalimat per kalimat lalu menerangkannya dengan bahasa Arab, Indonesia atau bahasa lainnya. Menurut Satria Hadi Lubis mengemukakan bahwa pelaksanaan metode halaqah tersebut, biasanya beberapa orang santri dengan jumlah tertentu membentuk halaqah yang dipimpin langsung oleh seorang kiyai atau ustadz atau mungkin juga santri senior untuk membahas atau mengkaji suatu persoalan yang telah ditentukan sebelumnya. ${ }^{11} \mathrm{Jadi}$, halaqah adalah sebuah istilah yang ada hubungannya dengan dunia pendidikan, khususnya pendidikan atau pengajaran Islam (tarbiyah Islamiyah). Istilah halaqah (lingkaran) biasanya digunakan untuk menggambarkan sekelompok kecil muslim yang secara rutin mengkaji ajaran Islam. Jumlah peserta mereka dalam kelompok kecil tersebut berkisar antara 3-12 orang. Mereka mengkaji Islam dengan manhaj (kurikulum) tertentu. Biasanya kurikulum tersebut berasal dari Guru (kiyai/guru) yang mendapatkannya dari jamaah (siswa) yang menaungi halaqah tersebut. Di beberapa kalangan, halaqah disebut juga mentoring, ta'lim, pengajian kelompok, tarbiyah atau sebutan lainnya

Dalam pelaksanaannya, para santri dengan bebas mengajukan pertanyaan-pertanyaan atau pun pendapatnya. Dengan demikian, halaqah memiliki arti diskusi untuk memahami isi kitab bukan untuk mempertanyakan kemungkinan benar salahnya yang diajarkan kitab. Santri yakin bahwa kiyai tidak akan mengajarkan hal-hal yang salah dan mereka juga yakin bahwa isi kitab yang dipelajarinya adalah kitab yang perlu untuk

\footnotetext{
${ }^{10}$ Azyumardi Azra, Jaringan Ulama Timur Tengah dan Kepulauan Nusantara Abad XVII dan XVII, (Bandung, Mizan, 1994), 65

${ }^{11}$ Satria Hadi Lubis, 114 Tips Murobbi Sukses "Panduan Untuk Para Pembina, Mentor Naqib dan Mereka yang Ingin Berhasi memimpin Kelompok Kecil, (Semarang, Pustaka Rizki Putera, 2014),18
} 
dipelajari. ${ }^{12}$ Metode pembelajaran halaqah ini lebih menitiberatkan kepada kemampuan perseorangan dalam menganalisa dan memecahkan suatu masalah dengan argumen logika pada kitab-kitab tertentu. ${ }^{13}$ Kiyai tampil dalam memimpin jalannya kegiatan proses pembelajaran biasanya menggunakan kitab/buku untuk dipahami oleh peserta didik, menguraikan nama judul sekaligus penulis kitabnya, menjelaskan pentingnya isi kitab yang akan dipelajari, mengajarkan tata cara atau qaidah sesuai ilmu bahasa terutama bahasa Arab sebagai penunjang dalam memahami isi kitab yang dipelajari.

\section{Konsep Dasar Metode Pembelajaran Halaqah}

Metode pembelajaran sistem halaqah merupakan tradisi yang telah diwariskan oleh para ulama klasik dalam pengembangan pendidikan Islam. Pelaksanaan metode pembelajaran halaqah ini, setiap pelajar memasuki ruangan tempat melaksanakan kegiatan belajar mengajar, biasanya menggunakan tempat yang luas kemudian duduk melingkar dengan membawa kitab sesuai dengan mata pelajaran dan pelajar semuanya menghadap ke arah guru (kiyai), sedangkan guru juga duduk berhadapan dengan para pelajar. Biasanya guru atau kiyai dan pelajar harus memegang kitab, umpanya kitab al-Mahalli. Ketika memulai pelajaran kiyai atau guru membaca matan kitab dalam bahasa Arab, kemudian menterjemahkannya. Pada masa awal perkembangan pesantren di Indonesia kiyai menterjemahkan dengan bahasa daerah dimana tempat kiyai melakukan kegiatan belajar mengajar, pada masa sekarang umumnya menjelaskan dengan bahasa Indonesia sedangkan para pelajar semuanya memperhatikan, menyimak dan mengikuti dengan sebaik-baiknya tentang penjelasan yang disampaikan oleh kiyai. Umumnya metode halaqah menggunakan sistem belajar tuntas. Tidak boleh meneruskan pelajaran atau kitab yang lain sebelum tuntas belajar kitab yang sedang dipelajari.

Metode pembelajaran halaqah tidak diatur waktunya sebagaimana sistem pembelajaran modern dengan interval waktu sesuai jumlah mata pelajaran pada setiap hari. Menurut Mahmud Yunus umumnya metode

\footnotetext{
${ }^{12}$ Maksum. Madrasah: Sejarah dan Perkembangannya. Jakarta: Logos Wacana Ilmu, 1999), 53

${ }^{13}$ Syamsul Nizal, Sejarah Sosial Dan Dinamika Intelektual Pendidikan Islam Di Nusantara, (Jakarta, Kencana, 2013), 164
} 
halaqah ketika mulai belajar pada dimulai pada pagi hari sekitar jam 08.0010.30 untuk tiga mata pelajaran. ${ }^{14}$ Kemudian dilanjutkan lagi malam hari sesudah shalat isya' sampai jam 10 malam untuk tiga mata pelajaran. Jadi jumlah pelajaran dalam sehari semalam sebanyak 6 mata pelajaran. Metode pembelajaran halaqah yaitu guru membuka dan menerangkan mata pelajaran, sedangkan murid memperhatikan penjelasan guru. Hal seperti ini hampir sama dengan sistem sekolah atau kuliah pada masa sekarang. Hanya perbedaanya pada sistem halaqah, murid terpusat perhatiannya pada kitabkitab mereka masing-masing. Sedangkan pada sistem sekolah, siswa mencatat pelajaran yang diberikan oleh guru.

\section{Strategis Metode Pembelajaran Halaqah}

1. Metode Sorogan

Istilah sorogan berasal dari kata sorong (Jawa) yang berarti menyodorkan. Setiap santri bergilir menyodorkan kitabnya dihadapan kiyai. ${ }^{15}$ Metode sorogan ini merupakan bagian yang paling sulit dari keseluruhan metode pendidikan Islam tradisional, sebab metode ini menuntut kesabaran, kerajinan, ketaatan dan kedisiplinan pribadi dari murid. ${ }^{16}$ Dalam metode ini, santri yang pandai mengajukan sebuah kitab kepada kiyai untuk dibaca dihadapan kiyai tersebut, jika terdapat kesalahan dalam membaca, maka kesalahan langsung dibetulkan oleh kiyai. metode ini dilakukan oleh santri permulaan belajar atau sebaliknya dilakukan oleh santri-santri khusus yang dikemudian hari diharapkan menjadi seorang alim. Dalam metode sorogan ini biasanya kiyai duduk di atas sajadah, dengan beberapa kitab di sampingnya yang diperlukan, sedangkan murid-muridnya mengelilinginya sambil melihat lembaran kitab yang dibacakan gurunya. Murid-murid tersebut menuliskan catatan-catatan dalam kitabnya mengenai arti dan keterangan lainnya. Setelah guru membaca kitab tersebut, menerjemahkannya dan memberikan keterangan yang perlu, maka dipersilahkan salah seorang murid membaca kembali. ${ }^{17}$ Dengan demikian,

\footnotetext{
${ }^{14}$ Mahmud Yunus, Sejarah Pendidikan Islam Di Indonesia, (Jakarta, Hidakarya Agung, 1993), 57

${ }^{15}$ M. Habib Chirzin, Agama dan Ilmu Pesantren, (Jakarta, LP3ES, 1983), h. 30

16 Asrori S Karni, Etos Study Kaum Santri: Wajah Baru Pendidikan Islam, (Bandung, Mizan, 2009), 65

${ }^{17}$ Asrori S Karni, Etos Study Kaum Santri...., 70
} 
murid itu terlatih dalam pimpinan gurunya, tidak saja dalam pengertian naskah-naskah Arab itu, akan tetapi juga dalam membaca bahasa arab dengan menggunakan pengetahuan ilmu bahasanya atau nahwu.

2. Metode Wetonan atau Bandongan

Wetonan istilah ini berasal dari kata wektu (bahasa jawa) yang berarti waktu, sebab pengajian tersebut diberikan pada waktu-waktu tertentu, yaitu sebelum dan atau sesudah melakukan shalat fardhu. metode wetonan ini merupakan metode kuliah, dimana para santri mengikuti pelajaran dengan duduk di sekeliling Kyai yang menerangkan pelajaran secara kuliah, santri menyimak kitab masing-masing dan membuat catatan padanya. Istilah wetonan ini di Jawa disebut dengan bandongan. Pelaksanaan metode ini yaitu, kiyai membaca, menerjemahkan, menerangkan dan seringkali mengulas teks-teks kitab berbahasa Arab tanpa harakat (gundul). Santri dengan memegang kitab yang sama, masing-masing melakukan pendhabitan harakat kata langsung di bawah kata yang dimaksud agar dapat membantu memahami teks.

Metode bandongan atau weton adalah sistem pengajaran secara kolektif yang dilakukan di pesantren. Disebut weton karena berlangsungnya pengajian itu merupakan inisiatif kiyai sendiri, baik dalam menentukan tempat, waktu, terutama kitabnya. Disebut bandongan karena pengajian diberikan secara kelompok yang diikuti oleh seluruh santri. Kelompok santri yang duduk mengitari kiyai dalam pengajian itu disebut halaqoh. Prosesnya adalah kiyai membaca kitab dan santri mendengarkan, menyimak bacaan kiyai, mencatat terjemahan serta keterangan kiyai pada kitab. H. Abdullah Syukri Zarkasyi, memberikan definisi tentang metode bandongan, yaitu, kiyai membaca kitab dalam waktu tertentu, santri membawa kitab yang sama, mendengarkan dan menyimak bacaan Kyai. ${ }^{18}$ Sedangkan Nurcholis Madjid memberikan definisi tentang metode weton. Menurutnya, weton adalah pengajian yang inisiatifnya berasal dari kiyai sendiri, baik dalam menentukan tempat, waktu maupun lebih-lebih lagi kitabnya. Senada dengan hal di atas, Hasbullah mendefinisikan tentang metode wetonan,

\footnotetext{
${ }^{18}$ Abdullah Syukri Zarkasyi. "Pondok Pesantren Sebagai Alternarif Kelembagaan Pendidikan untuk Program Pengembangan Studi Islam di Asia Tenggara", dalam Zainuddin Fananie dan M. Thoyibi. Studi Islam Asia Tenggara. (Surakarta: Muhammadiyah University Press, 1999), 75
} 
menurutnya, metode wetonan adalah metode yang di dalamnya terdapat seorang kiyai yang membaca kitab dalam waktu tertentu, sedangkan santrinya membawa kitab yang sama, lalu santri mendengarkan dan menyimak bacaan kiyai. Metode ini dapat dikatakan sebagai proses belajar mengaji secara kolektif. ${ }^{19}$ Dalam sistem ini sekelompok murid mendengarkan seorang guru yang membaca, menerjemahkan, menerangkan dan seringkali mengulas buku-buku Islam dalam bahasa Arab. Setiap murid memperhatikan bukunya sendiri dan membuat catatan-catatan (baik arti maupun keterangan) tentang kata-kata atau buah pikiran yang sulit.

\section{Kelebihan dan Kekurangan Metode Pembejalaran Halaqah}

1. Kelebihan metode pembelajaran halaqah

a. Kyai secara pasti mengetahui kualitas anak didiknya, bagi santri yang IQ nya tinggi akan cepat menyelesaikan pelajaran, mendapatkan penjelasan yang pasti dari seorang Kyai.

b. Melatih dan mendidik para santri/siswa belajar secara mandiri.

c. Hasil pelajaran lebih tahan lama dan membekas dalam ingatan santri/siswa.

d. Dengan pemahaman yang mendalam, mereka akan dapat dengan mudah memperaktekkan dan mengamalkan pengetahuan yang mereka dapatkan di pesantren.

e. Di samping itu bahan dapat disampaikan sebanyak mungkin dalam jangka waktu yang tidak terlalu lama. Organisasi kelas lebih sederhana dan mudah dilaksanakan karena tidak terlalu banyak memakan biaya dan tenaga.

f. Penggunaan sistem halaqah, khususnya dengan metode sorogan dapat mendorong terciptanya hubungan emosional yang intens antara sang ustadz atau kiai dengan santri/siswa.

2. Kelemahan Metode Pembelajaran halaqah

a. Kurangnya perhatian para santri/siswa terhadap sistem tersebut dibandingkan dengan sistem klasikal.

b. Para santri/siswa yang mengikuti kegiatan sistem halaqah ini ada yang kelihatannya kurang serius.

19 Hasbullah. Sejarah Pendidikan Islam di Indonesia: Lintasan Sejarah Pertumbuhan dan Perkembangan. Jakarta: Raja Grafindo Persada, 1995), 54 
c. Pembelajaran sistem halaqah ini dapat dikatakan lebih bersifat pilihan.

d. Tidak ada absen atau daftar hadir yang mengikat sehingga santri/siswa merasa bebas.

e. Tidak ada teguran dari kiai meskipun santri/siswanya tampak tidak sungguh-sungguh menerima pelajaran.

f. Tidak diciptakan instrumen yang dapat mengikat santri/siswa untuk mempertanggung jawabkan kemampuan mereka mengekspresikan ilmu-ilmu yang sudah diterima.

g. Teacher centre dalam proses pembelajaran dan santri/siswa banyak berperan sebagai pendengar setia.

h. metode ini membutuhkan waktu yang sangat banyak.

\section{Implikasi Metode Halaqah Terhadap Pembelajaran PAI dan BP}

Dalam upaya pengembangan metode pembelajaran halaqah di sekolah, yang menjadi pertimbangan bukan upaya untuk mengganti metode halaqah menjadi model persekolahan sebagaimana sistem pendidikan modern, melainkan adanya inovasi baru metode halaqah menjadi gaya belajar yang mutakhir (gaya baru). Dimaksudkan halaqah yang mutakhir ini sebagaimana praktik guru-guru selama ini. Mereka mengajar dengan metode halaqah. Siswa diberi tugas satu persatu pada waktu tatap muka yang terjadwal, setelah membaca diadakan pembahasan dengan cara berdialog dan berdiskusi sampai mendapatkan pemahaman yang jelas pada pokok bahasan. Sejalan dengan itu, tampaknya perlu dikembangkan di sekolah metode halaqah gaya mutakhir ini sebagai upaya pengembangan model pengajaran. Sudah barang tentu akan lebih lengkap apabila beberapa usulan metode sebagai alternatif perlu dipertimbangkan, seperti metode ceramah, kelompok kerja, tanya-jawab, diskusi.

Metode pembelajaran yang lebih baik ialah mempergunakan kegiatan murid-murid sendiri secara efektif dalam kelas, merencanakan dan melaksanakan kegiatan-kegiatan sedemikian rupa secara kontinyu dan juga melalui kerja kelompok. Pola pengembangan pembelajaran yang disebutkan di atas, dapat dituangkan ke dalam metode pembelajaran yang digunakan sewaktu mengajar. Salah satu yang aplikasi yang paling mendekati metode halaqah pada mata pejalaran PAI di sekolah difokuskan 
pada materi pemahaman tentang al-Qur'an dan/atau materi PAI yang lain dengan metode halaqah dengan metode kelompok yang beragam.

Pada materi pelajaran tentang cara membaca, menghafal dan memahami al-Qur'an dengan baik dan benar. Pada materi pemahaman alQur'an difokuskan pada materi cara membaca dan memahami al-Qur'an pada semester I kelas XII berdasarkan ilmu tajwid dan tafsir al-Qur'an. ${ }^{20}$ Sebagaimana metode halaqah dengan metode sorogan, bahwa kiyai atau ustadz mengajarkan ilmu duduk dikelilingi oleh para santri satu per satu menghadap kiyai dengan membawa kitab al-Qur'an. Pada sistem sekolah tidak perlu lagi siswa duduk melingkar dihadapan guru, kelas menjadi tempat belajar seperti biasanya. Sebagai langkah-langkah pembelajaran yang dilakukan antara lain:

\section{Tujuan Pembelajaran PAI}

Implementasi mata pelajaran Agama Islam tentang materi pemahaman al-Qur'an mendorong tingkat pencapaian pembelajaran peserta didik yang diarahkan untuk menyiapkan peserta didik untuk mengenal memahami, menghayati dan mengamalkan nilai-nilai ajaran Islam, yang kemudian menjadi dasar pandang hidupnya (way of life) melalui kegiatan bimbingan, pembiasaan dan pengamalan dalam kehidupan sehari-hari.

2. Strategi Pelaksanaan Pembelajaran PAI

a. Rambu-rambu

Cakupan materi pada setiap aspek pada materi dikhususkan pada pamahaman tentang ayat-ayat al-Qur'an, dikembangkan secara integral dalam seluruh rangkaian pelaksanaan pembelajaran di sekolah ditambah waktu khusus dalam menciptakan suasana kondusif bagi pelaksanaan materi penguatan ciri sekolah diluar struktur jam yang telah ada. Secara khusus kegiatan implementasi pada materi al-Qur'an adalah sebagai berikut:

1) Pengalaman, memberikan kesempatan kepada peserta didik untuk membacakan al-Qur'an sesuai dengan batasan bacaannya telah tentukan.

\footnotetext{
${ }^{20}$ Syamsuri, Pendidikan Agama Islam Untuk SMA Kelas XII, (Jakarta, Erlangga, 2007), 1
} 
2) Pembiasaan, memberikan kesempatan kepada peserta didik untuk membiasakan sikap dan perilaku tersebut untuk terus dilakukan pada setiap waktu luang melalui bimbingan.

3) Rasional, usaha memberikan peranan kepada rasio (akal) peserta didik dalam memahami dan membedakan berbagai materi bacaan serta kaitan dengan tata cara menghafal al-Qur'an.

4) Emosional, upaya menggugah peranan (emosi) peserta didik dalam menghayati perilaku yang sesuai dengan ajaran agama.

5) Fungsional, siswa mampu melakukan secara mandiri sesuai dengan bimbingan dan arahan.

6) Keteladanan, yaitu menjadikan figur pribadi teladan dan performan personal sekolah, sebagai cerminan yang teguh dan berakhlak karimah.

b. Pelaksanaan/Langkah-langkah

Pelaksanaan implementasi metode halaqah pada SMA diarahkan pada penguatan mata pelajaran Pendidikan Agama Islam melalui kegiatan pembiasaan membaca dan memahami al-Qur'an dengan kegiatan sebagai berikut:

1) Tema memahami Surah al-Kafirun ayat 1-6, surah Yunus ayat 40-41 dan surah al-Kahfi ayat 29.

2) Kegiatan yang termasuk dalam kelompok materi ini adalah:

a) Membiasakan membaca Alquran secara baik dan benar.

b) Guru membacakan ayat-ayat yang sudah ditentukan sesuai dengan materi.

c) Siswa mengikuti bacaan al-Qur'an setelah mendengarkan bacaan dari guru.

d) Setelah siswa selesai membaca dengan baik, guru memberikan penjelasan tentang cara membaca al-Qur'an (ilmu Tajwid), kandungan dan makna (tafsir) ayat yang telah dibaca dan

e) Siswa menghafal dengan baik ayat-ayat yang telah dibacakan.

Dengan demikian kegiatan ini diarahkan agar peserta didik membiasakan membaca al-Qur'an melalui kegiatan tadarus yang diadakan dengan pendampingan oleh guru dan waktu khusus pada jam pelajaran. 
Jurnal Ilmiah "Kreatif" Vol. 18 No. 2, Juli 2020

"Jurnal Studi Pemikiran Pendidikan Agama Islam"

\section{Penutup}

Inti metode halaqah adalah berlangsungnya proses belajar mengajar secara face to face antara Kyai dan santri. Keunggulan metode ini adalah Kyai secara pasti mengetahui kualitas anak didiknya, bagi santri yang IQ nya tinggi akan cepat menyelesaikan pelajaran, mendapatkan penjelasan yang pasti dari seorang Kyai. Kelemahannya metode ini membutuhkan waktu yang sangat banyak. Halaqah (lingkaran studi) merupakan forum kajian keilmuan yang sistem penyelenggaraanya dimulai dengan memberikan garis-garis umum mata pelajaran, dilanjutkan pelajaran secara detail dan mendalam tentang masing-masing sub materi. Lalu diakhiri dengan evaluasi dalam bentuk diskusi. Proses ini penekanannya terletak pada analisis dan pengembangan informal tentang pandangan seorang guru. Dengan demikian maka metode halaqah lebih banyak tergantung pada pengalaman dan pengetahuan sang guru disaat menempuh perjalanan keilmiahannya. Implementasi metode halaqah pada pembelajaran PAI dikhususkan pada materi pelajaran tentang cara membaca, menghafal dan memahami al-Qur'an dengan baik dan benar. Pada materi pemahaman alQur'an difokuskan pada materi cara membaca dan memahami al-Qur'an pada semester I kelas XII berdasarkan ilmu tajwid dan tafsir al-Qur'an.

\section{DAFTAR PUSTAKA}

Al-Mubarakhfuri, Syafiyyurrahman. Ar-Rahiqul Makhtum, Bahtsun fi AsSirah An-Nabawiyah ala Shahibina Aidhalish Shalati wa sallam, Terjemah Kathur Suhartdi, Sirah Nabawiyah. Jakarta, Pustaka AlKautsar, 2008.

Asrohah, Hanun. Sejarah Pendidikan Islam. Jakarta, Logos, 1994.

Azra, Azyumardi. Jaringan Ulama Timur Tengah dan Kepulauan Nusantara Abad XVII dan XVII. Bandung, Mizan, 1994.

Chirzin, M. Habib. Agama dan Ilmu Pesantren. Jakarta, LP3ES, 1983.

Hasbullah. Sejarah Pendidikan Islam di Indonesia: Lintasan Sejarah Pertumbuhan dan Perkembangan. Jakarta: Raja Grafindo Persada, 1995.

Hasan, Alwi. Kamus Besar Bahasa Indonesia. Jakarta, Balai Pustaka, tt.

Lubis, Satria Hadi. 114 Tips Murobbi Sukses "Panduan Untuk Para Pembina, Mentor Naqib dan Mereka yang Ingin Berhasi memimpin Kelompok Kecil. Semarang, Pustaka Rizki Putera, 2014. 
Jurnal Ilmiah "Kreatif" Vol. 18 No. 2, Juli 2020

"Jurnal Studi Pemikiran Pendidikan Agama Islam"

Karni, Asrori S. Etos Study Kaum Santri: Wajah Baru Pendidikan Islam. Bandung, Mizan, 2009.

Maksum. Madrasah: Sejarah dan Perkembangannya. Jakarta: Logos Wacana Ilmu, 1999.

Mahasnah, Muhammad Husain. adhwa 'ala Tarikh Al-Ulum inda AlMuslimin, Diterjemahkan oleh Muhammad Misbah, Pengantar Sejarah Peradaban Islam. Jakarta, Pustaka Al-Kautsar, 2016.

Munawwir, A.W. Kamus al-Munawwir. Surabaya, Pustaka Progressif, 1997.

Nizal, Syamsul, Sejarah Sosial Dan Dinamika Intelektual Pendidikan Islam Di Nusantara, (Jakarta, Kencana, 2013).

Nurdin, Syafruddin dan Adriantoni. Kurikulum dan Pembelajaran. Jakarta, Rajawali Pers, 2016.

Rusman, Model-Model Pembelajaran: Mengembangkan Profesionalisme Guru. Jakarta, Rajawali Pres, 2016.

Syalabi, Ahmad. At-Tarbiyyah wa At-Ta'lim fi Al-Fikr Al-Islami. Kairo, 1964.

Jalaluddin As-Suyuthi. Thabaqat Al-Huffazh, Dar Al-Kutub Al-Ilmiyyah, Dar Al-Kutub Al-Islamiyyah, Beirut.

Syamsuri, Pendidikan Agama Islam Untuk SMA Kelas XII. Jakarta, Erlangga, 2007.

Yunus, Mahmud, Sejarah Pendidikan Islam Di Indonesia. Jakarta, Hidakarya Agung, 1993.

Zarkasyi, Abdullah Syukri, "Pondok Pesantren Sebagai Alternarif Kelembagaan Pendidikan untuk Program Pengembangan Studi Islam di Asia Tenggara", dalam Zainuddin Fananie dan M. Thoyibi. Studi Islam Asia Tenggara. Surakarta: Muhammadiyah University Press, 1999. 